\title{
FAKTOR-FAKTOR YANG MEMPENGARUHI EFEKTIVITAS PENERIMAAN PESAN MAHASISWA DALAM KEGIATANBELAJAR MENGAJAR DI FAKULTAS TEKNOLOGI INFORMASI DAN KOMUNIKASI USM
}

\author{
Mochamad Chaerul Latief, R.A Putri Shakty A, Firdaus Azwar Ersyad \\ ${ }^{1}$ latief@usm.ac.id, ${ }^{2}$ Shakti@usm.ac.id, ${ }^{3}$ firdaus.azwar@usm.ac.id \\ ${ }^{1,2,3}$ Program Studi Ilmu Komunikasi Universitas Semarang
}

\begin{abstract}
ABSTRAK
Dapat mengenyam pendidikan tinggi adalah hak dan impian tiap warga negara Indonesia. Universitas Semarang sebagai institusi penyelenggara pendidikan tinggi memfasilitasi tiap warga Jawa Tengah dan seluruh Indonesia untuk mendaptkan pendidikan tinggi dengan harga yang terjangkau dan kualitas yang baik. Kegiatan belajar mengajarpundilakukan oleh para pengajar yang ahli di bidangnya. Namun dalam kenyataannya input dan output yang diharapkan kurang sesuai. Oleh karena itu, penelitian ini dibuat untuk melihat faktor-faktor apa saja yang mempengaruhi efektifitas penerimaan pesan dalamkegiatan belajar mengajar di Fakultas Teknologi Informasi dan Komunikasi.

Penelitian ini menggunakan pendekatan kualitatif yang memilii karakteristik data yang dinyatakan dalam keadaan sewajarnya atau sebagaimana adanya. Subjek kajian pada penelitian ini adalah individual yang menjadi narasumber utama dalam kegiatan belajar mengajar di Fakultas teknologi dan Informasi komunikasi. Adapun hasil penelitian yang telah dilakukan menjelaskan bahwa faktor kecakapan dalam berkomunikasi dosen sangat mempengaruhi penerimaan pesan mahasiswa dan cara dan gaya berbicara serta diksi atau pemilihan kata yang disampaikan mempengaruhi mahasiswa dalam menangkap pesan yang disampaikan.
\end{abstract}

Kata Kunci: Efektivitas, Kegiatan Belajar Mengajar, Kualitatif.

\subsection{Latar Belakang Penelitian}

Setiap warga negara di Indonesia pasti menginginkan dirinya dapat mengenyam pendidikan hingga level yang tertinggi apapun latar belakangnya dan apa pun status sosial ekonominya. Namun banyak yang tidak bisa mengenyam pendidikan tinggi karena tidak memiliki kemampuan finansial untuk membayar biaya pendidikan. Padahal pendidikan adalah wahana untuk memperbaiki kualitas hidup seseorang. Dengan mendapatkan pendidikan tinggi seseorang dapat memiliki wawasan yang luas, pola pikir yang terbuka, dan lebih cerdas secara intelektual serta emosional dalam menyelesaikan permasalahan. Selain itu sebagai bonus akhir, dengan memiliki pendidikan tinggi dapat meningkatkan taraf hidup seseorang. Menyadari bahwa fasilitas pendidikan tinggi masih belum bisa dinikmati secara merata di daerah luar ibu kota negara, Jakarta, maka Universitas Semarang memfasilitasi masyarakat se-Jawa Tengah dan sekitarnya bahkan hingga ke luar pulau Jawa agar dapat mengenyam pendidikan tinggi dengan harga yang terjangkau dan memiliki kualitas tinggi. Universitas Semarang mendirikan fakultas-fakultas yang dapat menjawab tantangan kebutuhan bisnis dan masyarakat, salah satunya Fakultas Teknologi Informasi dan Ilmu Komunikasi. Dunia kini berada di era digital dan era informasi dimana bidangbidang yang sedang populer di dunia bisnis berada di ranah Teknologi 
Informasi serta ranah Ilmu Komunikasi. Bidang-bidang spesifik seperti segala sesuatu yang berkaitan dengan komputer seperti software dan hardware, $e$ commerce, digital marketing, jurnalistik, public relations, dan broadcasting masih menjadi tren di dasawarsa terakhir.

Kurikulum yang dibuat oleh Fakultas Teknologi Informasi dan Ilmu Komunikasi pun dibuat agar dapat menjawab tantangan bisnis. Diharapkan dikemudian harinya para mahasiswa memiliki bekal ilmu yang sesuai dengan kebutuhan perusahaan-perusahaan tempat mereka bekerja nantinya. Agar dapat menyampaikan kurikulum yang sesuai dengan baik dan benar maka Fakultas Teknologi Informasi dan Ilmu Komunikasipun menyediakan para tenaga pengajar yang berkompeten dan ahli di bidang-bidang terkait. Kegiatan belajar mengajar diadakan dalam sarana dan prasarana yang baik yang telah disediakan oleh pihak Universitas Semarang. Namun permasalahan muncul ketika setelah mahasiswa menjalani perkuliahan, banyak yang tidak memahami dengan baik apa yang disampaikan oleh dosen. Terbukti dari hasil tes kecil yang diadakan memperlihatkan bahwa mahasiswa tidak dapat memaparkan dengan baik jawabanjawaban dari pertanyaan-pertanyaan yang dilontarkan dalam tes kecil tersebut. Selain itu mahasiswa banyak yang tidak mampu menulis maupun menyampaikan secara lisan pemikiran mereka. Asumsi para pengajar telah menyampaikan materi sesuai dengan silabus dan rencana pembelajaran yang telah dibuat. Menjadi ganjalan para pengajar bahwa dalam proses kegiatan belajar bahwa materi kuliah yang disampaikan tidak terserap dengan baik oleh para mahasiswa.

\subsection{Kerangka Pemikiran}

Kerangka pemikiran dalam penelitian ini dapat membantu menggambarkan konsep penelitian yang akan dilakukan terkait "Faktor-Faktor yang Mempengaruhi Efektivitas Penerimaan Pesan dalam kegiatan Belajar Mengajar di Fakultas Teknologi dan Informasi dan Komunikasi”.

\subsection{Komunikasi Dalam Pembelajaran}

Komunikasi dalam bahasa Inggris adalah communication, berasal dari kata commonicatio atau dari kata comunis yang berarti "sama" atau "sama maknanya" dengan kata lain komunikasi memberi pengertian bersama dengan maksud mengubah pikiran, sikap, perilaku, penerima dan melakukan yang diinginkan oleh komunikator. Menurut Roben komunikasi merupakan kegiatan perilaku atau kegiatan penyampaian pesan atau informasi tentang pikiran atau perasaan (Roben, 2008: 12). Selain itu, Frank Dance mendefinisikan bahwa komunikasi merupakan sebuah sistem untuk menyampaikan informasi dan perintah (Littejhon, 2009: 4).

Dengan demikian, dari konsep yang diutarakan para ahli komunikasi tersebut di atas dapat disimpulkan secara garis besar bahwa komunikasi adalah penyampaian informasi, gagasan, pikiran, perasaan, keahlian dari komunikator kepada komunikan untuk mempengaruhi pikiran komunikan dan mendapatkan tanggapan balik sebagai feedback bagi komunikator. Sehingga komunikator dapat mengukur berhasil atau tidaknya pesan yang di sampaikan kepada komunikan.

Dalam perkembangannya, model komunikasi terbagi atas berbagai macam model komunikasi. Ruliana dalam bukunya yang berjudul "Komunikasi Organisasi” memaparkan dua model komunikasi sebagai berikut:

\section{Model Komunikasi Linier}

Model komnikasi ini, merupakann ungkapan verbal yakni who (siapa), say what (apa yang dikatakan ), In Which 
Channel (salauran Pembicara Pesan Pendengar komunikasi), To Whom (kepada siapa), With What Effect? (unsur pengaruh). Model ini kemukakan oleh Harolld laswel tahun 1948 yang menggambarkan proses komunikasi dan fungsi-fungsi yang diembannya dalam masyarakat dan merupakan model komunikasi yang paling tua tetapi masih digunakan orang untuk tujuan tertentu. Berikut dibawah ini bagan dari model Komunikasi Laswell.

\section{Model komunikasi Interaksional}

Joseph Devito mengemukakan bahwa komunikasi mengacu pada tindakan satu orang atau lebih yang mengirim dan menerima pesan, terjadi dalam suatu konteks tertentu, mempunyai pengaruh tertentu dan ada kesempatan untuk melakukan umpan balik (feedback) yang dipengaruhi oleh lingkungan (konteks) dimana itu terjadi.

Gambar 2.2 Komunikasi Universal DeVito

Komunikasi Interaksional
$\begin{aligned} & \text { DeVito } \\ & \text { dikemukakan oleh }\end{aligned}$
mendiskripsikan bahwa komunikasi
interaksional mengandung elemen-
elemen yang ada dalam setiap tindakan
komunikasi, terlepas dari sifat
intrapribadi, antarpribadi, kelompok,
pidato terbuka atau komunikasi massa.
Model Komunikasi DeVito bersifat
interaksional karena kekuatan dari model
ini terletak pada sumber atau
komunikatornya. Adapun unsur
komunikasinya seperti gambar 2.2 di
atas.

Dalam ranah pendidikan tinggi komunikasi juga sangat berperan sangat penting dalam proses kegiatan pembelajaran. Kegiatan komunikasi tersebut merupakan proses pengiriman informasi dari Dosen kepada Mahasiswa untuk tujuan tertentu. Komunikasi dikatakan efektif jika komunikasi yang terjadi menimbulkan arus informasi dua arah, yaitu dengan munculnya feedback dari pihak penerima pesan. Dengan kata lain bahwa tujuan pendidikan akan tercapai jika prosesnya komunikatif.

Pembelajaran dapat dimaknai sebagai interaksi antara pengajar dengan peserta didik yang dilakukan secara sengaja dan terencana serta memiliki tujuan positif. Keberhasilan pembelajaran harus didukung oleh komponenkomponen instruksional yang terdiri dari pesan berupa materi belajar, penyampai pesan yaitu guru, bahan untuk menuangkan pesan, peralatan yang mendukung kegiatan belajar, teknik atau metode yang sesuai, serta latar atau situasi yang kondusif bagi proses pembelajaran

Dalam kegiatan pembelajaran, komunikasi yang efektif sangat membantu proses berjalannya kegiatan akedemik. Namun faktanya untuk mendapatkan komunikasi yang efektif pun juga tidak mudah. Banyak kesulitan yang terjadi yang diakibatkan komunikasi yang tidak efektif. Alvonco berasumsi bahwa hal tersebut terjadi karena adanya gangguan komunikasi yang disebabkan oleh dua faktor yaitu Faktor internal dan Eksternal. Adapun gangguan komunikasi karena faktor internal yaitu seperti: Cara berifikikir, perbedaan persepsi, faktor sikap, faktor pengetahuan dan ketrampilan, perbedaan status, permasalahan semantik atau bahasa, perbedaan budaya, gangguan fisik, dan melamun (Alvonco, 2014: 49).

Gangguan komunikasi yang kedua adalah ganguan karena faktor eksternal yang salah satunya gangguan 
kenyamanan lingkungan. Faktor ini terjadi dalam lingkungan yang dapat menyebabkan gangguan dalam proses komunikasi, bilamana komunikator tidak efektif dalam menyampaikan pesan dan komunikan juga sulit untuk mendengar pesan tersebut. Gangguan dapat berupa kebisingan, hiruk pikuk, cuaca, tata ruang yang tidak kondusif ataupun kondisi geografis.

\subsection{Efektivitas Pesan}

Komunikasi bisa dikatakan efektif jika: (1) pesan yang disampaikan dapat dipahami oleh komunikan. (2) Komunikan bersikap atau berperilaku seperti apa yang di kehendaki oleh komunikator. (3) ada kesesuaian antar komponen

Teori tentang efektivitas pesan yang berasumsi bahwa komunikasi diharapkan efektif maka pesan-pesannya perlu dikemas sedemikian rupa sehingga sesuai atau merupakan kebutuhan komunikan.

Komunikasi yang efektif menurut Kelman akan terjadi jika komunikan mengalami internalisasi (internalization), identifikasi diri (Self Identification) dan ketundukan (complience). Komunikan menalami proses internalisasi, jika komunikan menerima pesan yang sesuai dengan sistem nilai yang dianut. Komunikan merasa memperoleh sesuatu yang bermanfaat, pesan disampaikan memiliki rasionalitas yang dapat diterima. Internalisasi bisa terjadi jika komunikatornya memiliki ethos atau credibelity (ahli dan dapat dipercaya).

Identifikasi terjadi pada diri komunikan, jika komunikan merasa puas dengan meniru atau mengambil pikiran atau perilaku dari orang atau kelompok lain. Identifikasi akan terjadi pada diri komunikan jika komunikatornya memiliki daya tarik (attactiveness). Ketaatan pada diri komunikan terjadi, jika komunikan yakin akan mengalami kepuasan, mengalami reaksi yang memyenangkan, memperoleh reward (balasan positif) dan terhindar dari punishmen (keadaan, kondisi yang tidak enak) dari komunikator, jika menerima atau menggunakan isi pesannya.

Adapun faktor faktor yang dapat mempengaruhi efektivitas dalam komunikasi, baik faktor yang terjadi pada pengirim maupun pada penerima pesan, yaitu sebagai berikut:

1. Kemampuan berkomunikasi penyampai pesan seperti kemampuan bertutur dan berbahasa dan kemampuan menulis. Sedangkan faktor dari penerima pesan diantaranya kemampuan untuk menerima dan menangkap pesan seperti mendengar, melihat, dan menginterpretasikan pesan.

2. Sikap dan pandangan penyampai pesan kepada penerima pesan dan sebaliknya. Misalnya, rasa benci, pandangan negatif, prasangka, merendahkan satu diantara kedua belah pihak, sehingga akan menimbulkan kurangnya respon terhadap isi psan yang disampaikan.

3. Tingkat pengetahuan baik penerima maupun penyampai pesan. Sumber pesan yang kurang memahami informasi yang ingin dicapai akan mempengaruhi gaya dan sikap dalam proses penyampai pesan. Sebaliknya, penerima pesan yang kurang mempunyai pengetahuan dan pengalaman terhadap informasi yang disampaikan tidak akan mempu mencerna informasi dengan baik.

4. Latar belakang sosial budaya dan ekonomi penyampai pesan serta penerima pesan. Ketanggapan penerima pesan dalam merespon informasi tergantung dari siapa dan oleh siapa pesan itu disampaikan. 


\subsection{Teori Resepsi (Reception Theory)}

Menurut Nyoman Khuta Ratna (2012: 165) Secara umum teori resepsi diartikan sebagai penerimaan, penyambutan, tanggapan, reaksi, dan sikap komunikan terhadap suatu hal yang diberikan oleh komunikator. Secara definitif resepsi berasal dari kata recipere (latin), reception (Inggris), yang diartikan sebagai penerimaan. Dalam arti luas resepsi didefinisikan sebagai pengolahan teks, cara-cara pemberian makna terhadap karya, sehingga dapat memberikan respon terhadapnya.

\subsection{Kegiatan Belajar Mengajar}

Dalam bidang pendidikan, kegiatan belajar mengajar mempunyai peranan yang sangat vital untuk mencetak lulusan yang berkompeten. Kegiatan ini merupakan komponen utama dalam mencerdaskan kehidupan bangsa. Apabila dilihat dari suku katanya, Kegiatan Belajar Mengajar (KBM) terdapat dua macam aktivitas, yaitu belajar dan mengajar.

Belajar mengajar dapat diartikan sebagai perubahan tingkah laku pada diri individu berkat adanya interaksi antara individu dengan individu dan individu dengan lingkungannya sehingga mereka lebih mampu berinteraksi dengan lingkungannya.

Menurut Burton:

"Learning is a change in the individual due to instruction of that individual and his environment, which fells a need and make him more capable of dealing adequately his environment" (Upaya Optimalisasi Kegiatan Belajar Mengajar, 1993:4)

Terdapat kata change yang dalam Bahasa Indonesia berarti perubahan memiliki makna bahwa seseorang yang telah mengalami proses belajar akan mengalami perubahan tingkah laku, baik dalam aspek pengetahuan, keterampilannya, maupun dalam sikapnya. Perubahan tingkah laku dalam aspek pengetahuan ialah, dari yang tadinya belum atau tidak mengerti menjadi mengerti, dari bodoh menjadi pintar, dari aspek keterampilan, dari tidak bisa menjadi bisa, dari tidak terampil menjadi terampil; dalam aspek sikap ialah dari ragu-ragu menjadi yakin, dari tidak sopan menjadi sopan, dari kurang ajar menjadi terpelajar. Hal tersebut merupakan suatu kriteria keberhasilan belajar yang ditengarai dengan terjadinya perubahan tingkah laku, belajar dapat dikatakan tidak berhasil atau gagal.

Ernest R. Hilgard yang dikutip oleh Uzer Usman dan Lilis Setiawati (1993:5) berpendapat: "We may define learning as the process by which an activity ariginates or is changed through responding to a situation, provide the change cannot be attributed to growth or temporary state of the organism (as fatigue or under drugs)"'. Belajar adalah suatu proses dimana ditimbulkan atau perubahan karena mereaksi suatu keadaan, perubahan tersebut tidak disebabkan oleh proses pertumbuhan (kematangan) atau keadaan organisme yang sementara (seperti kelelahan atau karena pengaruh obat)".

H.C Witherington yang dikutip oleh Uzer Usman dan Lilis Setiawati (1993:5) mengemukakan bahwa "Belajar adalah suatu perubahan di dalam kepribadian yang menyatakan diri sebagai suatu pola baru dari reaksi berupa kecakapan, sikap, kebiasaan kepribadian atau suatu pengertian."

Ketiga definisi belajar dari beberapa pakar tersebut menunjukan bahwa belajar adalah suatu proses perubahan tingkah laku atau kecakapan manusia. Perubahan tingkah laku itu bukan disebabkan oleh proses pertumbuhan yang bersifat fisiologis atau proses kematangan. Perubahan yang terjadi karena belajar dapat berupa perubahan-perubahan kebiasaan (habit), kecakapan-kecakapan (skills) atau dalam ketiga aspek yakni pengetahuan 
(kognitif), sikap (afektif), dan ketrampilan (psikomotor). Kegiatan belajar merupakan kegiatan yang paling pokok dalam keseluruhan proses pendidikan. Hal ini mengandung arti bahwa berhasil tidaknya pencapaian tujuan pendidikan banyak bergantung kepada bagaimana proses belajar yang dialami oleh peserta didik atau siswa (M. Uzer Usman dan Lilis Setiawati, 1993:5).

Aktivitas lainnya dalam proses pendidikan ialah mengajar. Menurut Bruner yang dikutip oleh Uzer Usman dan Lilis Setiawati (1993:5) mengemukakan bahwa "Mengajar adalah menyajikan ide, problem, atau pengetahuan dalam bentuk yang sederhana sehingga dapat dipahami oleh setiap siswa."

Teknik untuk menyederhanakan bahan yang disajikan tersebut menurut Bruner adalah dengan cara enactive, iconic, dan symbolic. Penyajian enactive adalah penyajian suatu bahan pelajaran dalam bentuk gerak atau dalam bentuk psikomotor. Cara penyajian ini amat sederhana, konkret, bahkan dapat dikatakan primitif. Cara penyajian ini amat sederhana, konkret, bahkan dapat dikatakan primitif. Penyajian iconic, melibatkan penggunaan grafik dalam penyajian suatu ide, objek, dan prinsip. Cara penyajian ini lebih abstrak bila dibandingkan dengan penyajian enactive. Sedang penyajian symbolic adalah dengan menggunakan bahasa dan penyajian hendaknya mengikuti perkembangan jiwa anak. Dengan demikian, pengajar dapat memilih cara penyajian mana yang akan diterapkan dalam menyampaikan materi pelajarannya kepada siswanya, dengan memperhatikan tingkat perkembangan jiwa anak tersebut.

Oemar Hamalik (2010:44) dalam bukunya Proses Belajar Mengajar menuliskan setidaknya ada 6 kriteria atau pengertian mengajar yaitu:
1. Mengajar adalah menyampaikan pengetahuan kepada siswa didik atau siswa di sekolah.

2. Mengajar adalah mewariskan kebudayaan kepada generasi muda melalui lembaga pendidikan sekolah.

3. Mengajar adalah usaha mengorganisasi lingkungan sehingga menciptakan kondisi belajar bagi siswa.

4. Mengajar atau mendidik adalah memberikan bimbingan belajar kepada siswa.

5. Mengajar adalah kegiatan mempersiapkan siswa untuk menjadi warganegara yang baik sesuai dengan tuntutan masyarakat.

6. Mengajar adalah proses membantu siswa menghadapi kehidupan masyarakat sehari-hari.

Mengajar pada prinsipnya adalah membimbing siswa dalam kegiatan belajar. Dapat pula dikatakan bahwa mengajar merupakan suatu usaha mengorganisasi lingkungan dalam hubungannya dengan anak didik dan bahan pengajaran sehingga menimbulkan terjadinya proses belajar pada diri siswa. Pengertian ini mengandung makna bahwa pengajar dituntut untuk dapat berperan sebagai organisator kegiatan belajar siswa yang mampu memanfaatkan lingkungan, baik yang terdapat di dalam kelas maupun di luar kelas. Pengertian ini sejalan dengan apa yang dikemukakan oleh Burton bahwa "Teaching is the guidance of learning activities".

\subsection{Jenis Penelitian}

Peneliti menggunakan pendekatan kualitatif yang memiliki karakteristik data yang dinyatakan dalam keadaan sewajarnya atau sebagaimana adanya (natural setting) tanpa merubahnya ke dalam bentuk simbol-simbol atau bilangan (Nawawi, 1994:15). Objek penelitian kualitatif ini adalah seluruh bidang atau aspek kehidupan manusia. 
Sehingga prosedur penelitian akan menghasilkan data deskriptif berupa katakata tertulis dari orang-orang sebagai narasumber.

Dalam penelitian ini penulis menggunakan pendekatan kualitatif karena teknik ini sangat berguna dalam mengeksplorasi persoalan komunikasi pemasaran sebagaimana pendapat Broom \& Dozier (Broom \& Dozier, 1990: 25) mengenai penggunaan metode ini yaitu bahwa sebagian besar teknik pengamatan kualitatif mengumpulkan informasi yang rinci dari beberapa studi kasus.

Metode kualitatif juga memungkinkan peneliti untuk mengenal narasumbernya secara pribadi dan mengikuti bagaimana narasumbernya itu mengembangkan definisinya tentang fenomena dan dunia melalui data yang dimiliki seseorang, idealisme, harapannya, dan lain-lain. Sehingga pada akhirnya individu tersebut mampu mengimplementasi konsep-konsepnya dalam suatu organisasi tempatnya berada (Sanapiah, 1990: 28).

\subsection{Sumber data}

Data merupakan keteranganketerangan yang diproleh dari suatu penelitian dan data tersebut nantinya akan diperlukan untuk menganalisis permasalahan maupun problema yang dihadapi. Untuk selanjutnya data tersebut digunakan untuk mencari alternatif pemecahan yang dirasa sesuai dan paling efektif. Dalam rangka pengumpulan data dan informasi maka menggunakan data sebagai berikut:

\section{a. Data Primer}

Data Primer merupakan data utama yang secara langsung diperoleh dari sumber data dari peneliti guna mencapai tujuan penelitian. Adapun dalam hal ini yang merupakan sumber data primer adalah mahasiswa Ilmu Komunikasi semester 1 hingga 6 yang menjabat sebagai ketua kelas di kelasnya yang dianggap dapat mewakili pemikiran mahasiswa Ilmu Komunikasi Universitas Semarang.

b. Data Sekunder

Data sekunder merupakan data yang diperoleh dengan mengumpulkan data-data berupa buku-buku ilmiah serta literatur-literatur yang relevan dengan masalah yang dibahas dalam penelitian ini.

\subsection{Sifat Penelitian}

Sifat penelitian ini adalah deskriptif yang bertujuan menggambarkan secara tepat sifat-sifat suatu individu, keadaan, gejala, atau kegiatan-kegiatan tertentu (Patton Quinn Michael, 2006: 30). Penelitian deskriptif ditujukan untuk mengumpulkan informasi aktual secara terperinci yang melukiskan gejala yang ada dan mendefinisikan masalah atau memeriksa kondisi dan praktek-praktek yang berlaku. Penelitian seperti ini biasanya dilakukan tanpa hipotesa yang telah dirumuskan secara ketat dan meskipun ada-tidak dilakukan uji statistik (Rachmat Jalaludin, 1985: 29). Dengan demikian penulisan penelitian ini berjalan menggambarkan atau mendeskripsikan dan kemudian menganalisa pernyataanpernyataan mengenai Faktor-Faktor yang Mempengaruhi Efektivitas Penerimaan Pesan dalam kegiatan Belajar Mengajar di Fakultas Teknologi dan Informasi dan Komunikasi.

\subsection{Strategi Penelitian}

Strategi penelitian ini adalah penelitian studi kasus. Studi kasus (case study) adalah penelitian tentang status subjek penelitian yang berkenaan dengan suatu fase spesifik atau khas dari keseluruhan personalitas. Studi kasus merupakan cara yang paling lazim digunakan dalam penelitian kualitatif.

Kelemahan studi kasus terdapat pada jumlah informan yang terlalu kecil sehingga sulit dibuat inferensi kepada 
populasi. Di samping itu studi kasus sangat dipengaruhi oleh pandangan subjektif dalam pemilihan kasus karena adanya sifat khas yang dapat saja terlalu dibesar-besarkan. Studi kasus dapat memberikan atau menghasilkan hipotesahipotesa untuk penelitian lanjutan. Dari segi edukatif maka studi kasus dapat digunakan sebagai contoh ilustrasi baik dalam perumusan masalah, penggunaan statistik dalam menganalisa data serta cara-cara perumusan generalisasi dan kesimpulan (Nazir, Moh. PhD, 1988: 25).

\subsection{Subjek Kajian}

Subjek kajian atau unit analisis yang ditentukan dalam penelitian ini adalah individual yang menjadi narasumber utama dalam kegiatan Belajar Mengajar di Fakultas Teknologi dan Informasi dan Komunikasi. Narasumber utama merupakan beberapa mahasiswa Ilmu Komunikasi semester 1 hingga 6 yang menjabat sebagai ketua kelas di kelasnya yang dianggap dapat mewakili pemikiran mahasiswa Ilmu Komunikasi Universitas Semarang.

\subsection{Metode Pengumpulan Data}

Teknik pengumpulan data yang digunakan untuk memperoleh data yang memenuhi standar data yang ditetapkan dalam penelitian ini adalah dengan melakukan wawancara mendalam (in depth interview) dan studi kepustakaan. Catherine Marshall, Gretchen B. Rossman dalam buku yang ditulis oleh Sugiyono (2009: 63) menyatakan bahwa "the fundamental methods relied on by qualitative researchers for gathering information are, participation in the setting, direct observation, in-depth interviewing, document review.

Data penelitian ini diperoleh dengan cara pengumpulan data sebagai berikut:

1. Studi kepustakaan

Studi kepustakaan dilakukan untuk mendapatkan gambaran umum secara teoritis dan konseptual mengenai berbagai hal yang berkaitan dengan efektivitas penerimaan pesan dan kegiatan belajar mengajar Ilmu Komunikasi Universitas Semarang.

2. Wawancara Mendalam

Peneliti melakukan wawancara mendalam dan tidak terstruktur kepada narasumber. Daftar pertanyaan digunakan sebagai panduan yang dapat dikembangkan lagi dalam wawancara. Meskipun demikian diskusi selalu tertuju pada pokokpokok permasalahan. Sesuai dengan ciri-ciri pengumpulan data dalam penelitian kualitatif yang berupa kalimat atau kata-kata, maka data yang diperoleh bukan bilangan atau angkaangka.

Dalam buku James E. Grunig \& Todd Hunt, Managing Public Relations disebutkan bahwa penelitian kualitatif dapat menggunakan dua jenis wawancara yaitu:

1. Wawancara yang berlangsung tidak resmi

Pada proses wawancara yang berlangsung tidak resmi, peneliti membahas program yang sedang dicari tahu tanpa ada dugaan apa yang akan terjadi berikutnya.

2. Wawancara yang berdasarkan panduan

Pada wawancara berdasarkan panduan, peneliti mencari efek tertentu tanpa memberikan pertanyaan yang terstruktur. Dengan pertanyaan yang bersifat terbuka atau kuesioner, peneliti memberikan pertanyaan yang sama pada setiap responden contohnya mengenai komunikasi, agama, ataupun perilaku, membuka jalan bagi para responden dalam berkomunikasi di suatu organisasi, apa yang diyakini, ataupun apa yang telah dilakukan oleh si responden (Grunig James. E, 1984: $105)$.

\subsection{Proses Analisis Data}

Teknik pengumpulan data dalam penelitian ini adalah wawancara individual terhadap informan. Sementara 
wawancara dilaksanakan dengan daftar pertanyaan terbuka yang telah dipersiapkan sebelumnya agar diskusi terfokus pada konteks pembahasan namun tidak menutup kemungkinan pertanyaan tersebut dikembangkan asal tidak menyimpang dari permasalahan yang dibahas.

\section{Hasil Penelitian}

Penelitian yang dilakukan merupakan upaya menjawab fenomena yang terjadi seperti bagaimana cara dosen sebagai komunikator berkomunikasi dengan mahasiswa ketika melakukan pengajaran, bagaimana mahasiswa penerimaan pesan yang diberikan dosen, faktor-faktor apa saja yang mempengaruhi hambatan dalam penyampaian materi dalam kegiatan belajar mengajar, serta solusi yang dapat dilakukan agar materi yang disampaikan dapat terserap dengan baik dan benar.

Dalam kegiatan belajar mengajar terdapat proses komunikasi linier maupun interaksional dimana baik pengajar (Dosen) maupun mahasiswa memiliki peran sebagai komunikator dan komunikan di waktu yang bersamaan. Dosen sebagai tenaga pengajar dan pendidik mengkomunikasikan materi perkuliahan baik secara verbal maupun non verbal. Secara verbal Dosen memberikan penjelasan materi dengan memberikan ceramah di kelas, diskusi, serta tanya-jawab. Secara non verbal Dosen menggunakan slide atau alat bantu lainnya seperti internet dan komputer, dan alat peraga untuk memberikan pemahaman secara holistik yang dibantu melalui media visual. Model komunikasi Laswell dimana komunikasi merupakan ungkapan verbal yakni who (siapa), say what (apa yang dikatakan), In Which Channel (saluran Pembicara Pesan Pendengar komunikasi), To Whom (kepada siapa), With What Effect (unsur pengaruh) telah terangkum dalam kegiatan belajar mengajar di Jurusan Ilmu Komunikasi Universitas Semarang. Jurusan Ilmu Komunikasi Universitas Semarang memiliki kurikulum yang mencakup ranah penyiaran, public relations, jurnalistik, periklanan, dan ilmu sosial lainnya. Cara Dosen berkomunikasi disesuaikan dengan tiap-tiap bidang yang diajar. Di ranah periklanan maka Dosen akan membuat suasana yang menyenangkan dan kreatif karena bidang iklan membutuhkan ideide segar yang kreatif yang hanya bisa muncul ketika seseorang dalam suasana hati yang senang dan bahagia. Dosen berperan besar dalam menciptakan suasana kelas yang demikian. Dalam tiap mata kuliah yang diberikan dosen memberikan teori-teori serta konsepkonsep serta contoh atau pengaplikasiannya kehidupan nyata.

Permasalahan muncul ketika dalam proses belajar mengajar terdapat proses komunikasi yang tidak efektif sehingga kegiatan belajar mengajar yang dilakukan tidak menghasilkan feedback yang diharapkan. Pengajaran dilakukan agar mahasiswa dapat memahami suatu gejala sosial atau permasalahan sosial tertentu namun temuan di lapangan bahwa mahasiswa tidak sepenuhnya memahami apa yang dijelaskan oleh Dosen atau mengerjakan sesuai dengan instruksi dari Dosen. Hal ini terbukti dari hasil evaluasi seperti kuis, ujian tengah semester, maupun ujian akhir semester. Sebagai pengajar tujuan utama dari kegiatan belajar mengajar adalah mahasiswa memahami secara keseluruhan materi yang diberikan dan bersikap serta bertindak sesuai dengan instruksi dan target pencapaian yang sudah di rencanakan.

Komunikasi dua arah tidak dapat terjadi apabila tidak adanya koneksi antara pemberi dan penerima pesan. Tahap awal untuk terkoneksi antar individu adalah melalui perkenalan. Setiap awal perkuliahan dosen akan 
memperkenalkan dirinya ke hadapan mahasiswa. Mahasiswa yang masuk ke perkuliahan rata-rata hanya mengetahui nama panggilan dosennya namun tidak banyak yang mengingat nama lengkap dosen dengan dalih lupa atau memang bukanlah suatu kebutuhan mereka untuk mengingat nama lengkap dosen.

Manusia cenderung menerima pesan yang diberikan apabila pemberi pesan adalah orang yang memiliki kuasa, berwenang, berkuasa, atau memiliki jabatan. Dosen memiliki kewenangan di kampus sebagai pengajar dimana dalam peraturan Universitas, mahasiswa mendapatkan pengajaran dari para Dosen. Dalam hal ini dosen memiliki kuasa atau jabatan dalam perkuliahan. Mahasiswa cenderung mendengarkan materi yang diberikan oleh dosen yang disenangi karena dosen tersebut memiliki kemampuan dalam menghantarkan materi dengan bahasa yang mudah dimengerti. Mahasiswa mengetahui nama dosen yang mengajar mereka hanya terkadang lupa nama lengkap serta gelar akademis dosen. Mahasiswa juga banyak yang tidak mengetahui profil dosen seperti latar belakang akademis, pengalaman kerja, serta keahlian dosennya masing-masing. Ada dosen yang memberitahukan profil mereka ketika pertemuan pertama kuliah ada yang tidak. Ketika dosen tidak memberikan keterangan lebih lanjut mengenai profilnya, maka mahasiswapun tidak berusaha mencari tahu lebih lanjut dengan alasan belum diperlukan atau hanya malas mencari tahu. Mahasiswa mengetahui kompetensi lain dari dosen apabila dosen tersebut datang dari kalangan praktisi.

Mahasiswa mulai mengerti karakter masing-masing dosen dengan melihat kebiasaan yang dilakukan. Materi sering sulit dicerna oleh mahasiswa karena mahasiswa tidak dapat memahami kalimat yang dilontarkan. Mahasiswa sering tidak mengerti istilah teknis dan ilmiah yang membuat mereka bingung sehingga tidak memahami makna kalimat secara holistik. Mahasiswa membutuhkan waktu yang cukup lama untuk memahami setiap perkataan dari dosen. Mahasiswa membutuhkan waktu untuk membaca sendiri serta mengeksplorasi sendiri materi yang diberikan agar mendapatkan pemahaman yang holistik.

Mahasiswa mengatakan bahwa $80 \%$ dosen memiliki kemampuan berkomunikasi yang baik dalam arti jelas dalam menyampaikan materi serta interaktif. Namun ada juga dosen yang kemampuan berkomunikasinya kurang baik dalam arti tidak mampu menyampaikan isi pikirannya dalam kalimat yang tepat. Pemilihan diksi yang tepat dan lebih kekinian membuat mahasiswa lebih mengerti apa yang disampaikan dosen. Istilah teknispun akan sulit dicerna oleh mahasiswa karena mereka belum memiliki banyak pengetahuan serta adanya "gap" generasi yang menyebabkan perbedaan tren bahasa.

Mahasiswa juga menyatakan bahwa terkadang mereka sulit memahami keinginan dosen. Terkadang dosen menampilkan emosi yang tidak dapat dipahami penyebabnya dan terbawa ketika mereka mengajar di kelas. Mahasiswa melihat dosen sebagai sosok yang mengetahui segala hal di dunia ini sehingga mahasiswa menuntut dosen untuk dapat menjawab semua pertanyaan mereka. Ada kalanya dosen tidak bisa menjawab pertanyaan mahasiswa dan mahasiswa menangkap ketidakmampuan tersebut sehingga mahasiswa tidak merasa puas. Efek dari rasa ketidakpuasan tersebut adalah turunnya kepercayaan mahasiswa terhadap dosen sehingga mereka malas untuk bertanya kembali. Untuk mata kuliah tertentu mahasiswa banyak yang tidak memahami materi karena mereka merasa tidak memahami jalan pemikiran dosennya yang terlalu kompleks. Mahasiswa sering berbeda persepsi dengan apa yang 
disampaikan oleh dosen karena pandangan mereka masih sangat subjektif akan suatu isu.

Mahasiswa juga sulit menangkap pesan karena ruang kelas yang terlalu dingin atau terlalu panas atau terlalu sempit. Selain itu juga banyaknya mahasiswa di dalam kelas dapat membuat bising sehingga materi sulit diterima karena noise atau gangguan yang tinggi. Selain itu fasulitas LCD di kelas sering mati sehingga media yang seharusnya bisa mempermudah pemahaman mahasiswa tidak dapat digunakan.

\subsection{Kesimpulan}

Penelitian yang dilakukan berkenaan dengan faktor-faktor yang mempengaruhi efektivitas penerimaan pesan dalam kegiatan belajar mengajar di jurusan Ilmu Komunikasi Universitas Semarang dapat diinterpretasikan sebagai berikut:

1. Bahwa faktor kecakapan dalam berkomunikasi dosen sangat mempengaruhi penerimaan pesan mahasiswa.

2. Cara dan gaya berbicara serta diksi atau pemilihan kata yang disampaikan mempengaruhi mahasiswa dalam menangkap pesan yang disampaikan.

3. Ruang kelas yang terlalu dingin atau terlalu panas juga dapat mempengaruhi suasana belajar.

Penelitian ini diharapkan dapat menjadi sumbangsih bagi Jurusan Ilmu Komunikasi Universitas Semarang agar dapat lebih baik lagi dalam melayani mahasiswa.

\section{DAFTAR PUSTAKA}

Alvonco, Johnson. 2014, Practical Communication Skill, Jakarta: Elex Media Komputindo.

Fiske, J., 2014. Pengantar Ilmu Komunikasi. Jakarta: Rajawali.

Littlejohn, Stephen W. 2008. Teori Komunikasi, Jakarta: Salemba Humanika.

Moleong, Lexy J.2014. Metode Penelitian Kualitatif. Bandung: Remaja Rosdakrya

Pawito, 2008. Penelitian Komunikasi Kualitatif. Yogyakarya: LKiS.

Poppy, Ruliana. 2014. Komunikasi Organisasi Teori dan Studi Kasus, Jakarta: Rajawali Pers.

Sunarwinadi, Ilya.2015. Teori-Teori Komunikasi Dalam Pengaruh Psikologi, Jakarta: Indeks. 